\title{
Is there diagnostic and prognostic importance of serum anti-p53 antibody level in lung cancer?
}

\section{Akciğer Kanserinde serum anti-p53 antikor düzeyinin tanısal ve prognostik önemi var mı?}

\author{
Zekiye Hasbek ${ }^{1}$, Birsen Yücel ${ }^{2}$, Ömer Tamer Doğan ${ }^{3}$, Serdar Berk ${ }^{3}$, İsmail Sarı ${ }^{4}$, Yavuz Silig ${ }^{5}$, \\ Mehmet Metin Șeker ${ }^{6}$, Seyit Ahmet Errtürk ${ }^{1}$
}

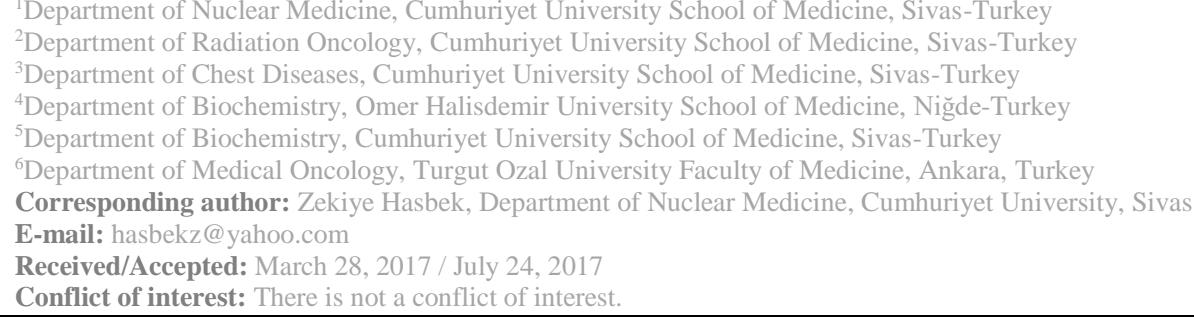

\section{SUMMARY}

Objective: Lung cancer is the leading cause of cancer-related deaths worldwide. Despite advancement in diagnostic tools and treatment options with technological developments, overall mortality rates in lung cancer patients remains high. Survival rates in lung cancer patients is low especially in advanced diseased inoperable patients in spite of new treatment options like immunotherapy. $\mathrm{p} 53$ is mutated in $60-70 \%$ of cancer patients and for this reason has been extensively studied recent researches suggest that serum anti-p53Ab can be considered as biomarkers to detect many types of cancers; as ovarian cancer, esophageal cancer, breast cancer and lung cancer. In this study we aimed that are there any diagnostic and prognostic importance of serum anti-p53Ab levels in lung cancer patients.

Method: Patients were included who were referred to our department with the purpose of ${ }^{18} \mathrm{~F}$-FDG-PET/CT imaging for staging due to lung cancer diagnosis (LC) and patients who were performed ${ }^{18} \mathrm{~F}-\mathrm{FDG}$-PET/CT for diagnosis in the cause of the suspected pulmonary nodule in thorax CT but not detected pathologic FDG accumulation (NAPN=pulmonary nodule with non-avid-FDG) and healthy volunteers. Serum anti-p53Ab levels were measured with ELISA method in the all patients. Mean follow up time of patients were 13 months.

Results: A total of $65 \mathrm{LC}$ patients $(58 \mathrm{M} / 7 \mathrm{~F}), 47$ patients with NAPN $(20 \mathrm{M} / 27 \mathrm{~F})$, and a total of 34 healthy volunteers $(26 \mathrm{M} / 8 \mathrm{~F})$ were included in this study. Median serum anti-p53Ab levels are $3.4 \mathrm{ng} / \mathrm{mL}$ in LC patients, $3.77 \mathrm{ng} / \mathrm{mL}$ in NAPN patients, $3.07 \mathrm{ng} / \mathrm{mL}$ in healthy volunteers. There is no statistically significant difference for serum anti-p $53 \mathrm{Ab}$ level between LC patients and NAPN patients $(p=0.678)$. Moreover there is no statistically significant difference for serum anti-p53Ab level between patients and healthy volunteers $(p=0.377)$. Two-year median survival of patients was 14 month. It has been found that there is no effect of serum anti-p53Ab level whether $>3.4$ or $\leq 3.4$ on the patient survival rate $(p=0.652)$.

Conclusions: Even though anti-p53Ab is very important in carcinogenesis, we think that serum anti-p53Ab level by itself is not important in lung cancer diagnosis and survival rates. There are multiple factors in carcinogenesis and this may be the reason of this situation. There is no known cut off value of serum anti-p53 Ab levels for diagnosis of lung cancer patients. Therefore we think that this antibody is not tumor spesific and serum anti-p53 Ab level measurement is not appropriate for lung cancer screening.

Keywords: Anti-p53Antibody, lung cancer, F18-FDG, PET, p53

\section{ÖZET}

Amaç: Akciğer kanseri dünya genelinde kansere bağlı ölümlerin önde gelen nedenidir. Tanısal cihazlar ve teknolojik geliş̧melere bağlı tedavi seçeneklerinde ilerlemeye rağmen, akciğer kanseri hastalarında genel mortalite oranı hala yüksektir. Akciğer kanseri hastalarında sağkalım oranları, özellikle ilerlemiş inoperabl hastalıkta, immunoterapi gibi yeni tedavi seçeneklerine rağmen düşüktür. p53, kanser hastalarının \%60-70'inde mutasyona uğramaktadır ve bu nedenle son zamanlarda yapılan çalışmalar göstermektedir ki, serum anti-p53 antikorunun, over, özefagus, meme ve akciğer kanseri 
gibi bazı kanser türlerinin dedekte edilmesinde biyobelirteç olarak dikkate alınabilir. Bu çalıșmada, akciğer kanseri hastalarında, serum anti-p53antikor düzeylerinin tanısal ve prognostik önemini araştırmayı amaçladık.

Yöntem: Çalışmaya akciğer kanseri (AK) tanısı nedeniyle evreleme için ${ }^{18} \mathrm{~F}-\mathrm{FDG}-\mathrm{PET} / \mathrm{BT}$ görüntüleme amacı ile bölümümüze sevk edilen hastalar, toraks BT'sinde şüpheli pulmoner nodül olup, patolojik FDG birikimi göstermeyen hastalar (NAPN= Non-avid FDG gösteren pulmoner nodül) ve sağlıklı gönüllüler dahil edildi. Serum anti-p53antikor düzeyleri tüm hastalarda ELISA yöntemi ile ölçüldü. Hastaların ortalama takip süresi 13 ay idi.

Bulgular: Çalışmaya toplam 65 AK hastası (58E/7K), 47 NAPN hastası (20E/27K) ve 34 sağlıklı gönüllü (26E /8K) dahil edildi. Ortalama serum anti-p53antikor seviyeleri AK hastalarında $3.4 \mathrm{ng} / \mathrm{mL}$, NAPN hastalarında $3.77 \mathrm{ng} / \mathrm{mL}$, sağlıklı gönülllülerde $3.07 \mathrm{ng} / \mathrm{mL}$ idi. AK hastaları ile NAPN hastaları arasında serum anti-p53antikor düzeyi için istatistiksel olarak anlamlı fark yoktu ( $\mathrm{p}=0.678)$. Hatta, hastalar ve sağlıklı gönüllüler arasında serum anti-p53Ab düzeyi için istatistiksel olarak anlamlı fark yoktu $(\mathrm{p}=0.377)$. Hastaların iki yıllık medyan sağkalımı 14 aydı. Hastaların sağkalım hızında, serum anti-p53Ab düzeyinin $>3.4 \mathrm{ng} / \mathrm{mL}$ veya $\leq 3.4 \mathrm{ng} / \mathrm{mL}$ olmasının herhangi bir etkisinin olmadığı bulundu $(\mathrm{p}=0.652)$.

Sonuç: Anti-p53antikoru, karsinogeneziste çok önemli olmasına rağmen, serum anti-p53antikor düzeyinin akciğer kanseri tanısında ve sağkalım oranlarında tek başına önemli olmadığını düşünüyoruz. Karsinogeneziste birden fazla faktör vardır ve bu durumun nedeni olabilir. Akciğer kanseri hastalarının teşhisi için serum anti-p53antikor düzeylerinin bilinen bir katof değeri yoktur. Bu nedenle, bu antikorun tümör spesifikliği olmadığını ve serum anti-p53antikor düzeyinin akciğer kanseri taraması için uygun olmadığını düşünüyoruz.

Anahtar sözcükler: Anti-p53antikor, akciğer kanseri, F18-FDG, PET, p53

\section{INTRODUCTION}

Lung cancer is one of the most common cancer worldwide. Long-term survival rates in lung cancer have been still low in spite of developing surgical tecniques, chemotherapy regimens and radiotheraphy methods ${ }^{1}$. Whereas surgical resection is the main treatment in early stage non small cell lung cancer, chemoradiotheraphy combination is the main treatment option in advanced stage lung cancers and small cell lung cancers. But treatment is given for only paliation and overall mortality of advanced stage lung cancer patients is high ${ }^{2}$. Therefore staging of lung cancer is very important for optimal treatment choice. High-resolution CT is the main diagnostic method for evaluating local tumor status. National Lung Screening Trial in the USA showed that early detection of lung cancer using low dose spiral computed tomography screening led to a $20 \%$ reduction in lung cancer mortality ${ }^{3}$. But using of thorax CT as a screening tool for lung cancer is limited because of radioactivity exposure and low specifity. Suspicious lesions which detected in thorax CT must be evaluated with integrated positron emission tomography/computed tomography (PET/CT) with 2-[ $\left.{ }^{18} \mathrm{~F}\right]$ fluoro-2-deoxyD-glucose $\left({ }^{18} \mathrm{~F}-\mathrm{FDG}\right)$. This method give chance of anatomical and metabolic evaluation of lesion ${ }^{4}$. Diagnostic accuracy, staging, treatment optimisation, evaluation of treatment response, radiotheraphy planning, restaging and prognostication are very important in lung cancer patients. Metabolic and volumetric parameters of PET such as SUVmax and total lesion glycolysis (TLG) have roles in prognosis of SCLC and
NSCLC patients ${ }^{5,6}$.

Tumor markers such as prostate-specific antigen (PSA), carcinoembriyonic antigen (CEA), cancer antigen CA15-3, cancer antigen CA19-9 and cancer antigen CA125 are used for both diagnosis and follow up in some types of cancers. But unfortunately there is no spesific tumor marker in lung cancer patients despite lung cancer has highest prevalance, incidence, mortality and morbitiy rates in worldwide.

Autoantibodies that react with autologous cellular antigens have been described in pre-diagnostic and diagnostic samples from patients with small cell, non-small cell and other forms of lung cancer, and can sometimes be correlated with clinicopathological parameters ${ }^{7}$.

p53 gene is mutated in $60-70 \%$ of cancer patients ${ }^{8}$. In the serum of healthy subjects, the presence of p53 protein and anti-p53 antibodies are extremely rare $^{9}$. Antibodies against p53 can be detected in serum samples. Recent researches suggest that serum p53-Abs can be considered as biomarkers to detect many types of cancer, as ovarian cancer, esophageal cancer, breast cancer and lung cancer 9-12.

In this study we aimed that are there any diagnostic and prognostic importance of serum anti-p53 Ab level in lung cancer patients.

\section{MATERIAL AND METHODS}

\section{Patients}

Patients were included who were referred to our 
department with the purpose of ${ }^{18} \mathrm{~F}-\mathrm{FDG}$-PET/CT imaging for staging due to lung cancer (LC) diagnosis and patients who were performed ${ }^{18} \mathrm{~F}$ FDG-PET/CT for diagnosis in the cause of the suspected pulmonary nodule in thorax $\mathrm{CT}$ but not detected pathologic FDG accumulation (NAPN=pulmonary nodule with non-avid-FDG) and healthy volunteers (control group). Only serum anti-p53 Ab levels were evaluated in conrol group. $\mathrm{PET} / \mathrm{CT}$ imaging were not performed those patients in control group. Patients had operated for LC, received prior chemotherapy or radiotherapy for lung cancer, and a blood glucose level greater than $150 \mathrm{mg} / \mathrm{dL}$ were excluded from the study. This study was performed in accordance with the principles of the Declaration of Helsinki. This study was approved by the local ethical committee. Oral and written consent was obtained from all patients.

\section{Detection of serum anti-p53 antibodies}

Blood samples were collected from peripheral blood vessels. Blood samples were taken before the FDG administration was performed with ${ }^{18} \mathrm{~F}-\mathrm{FDG}$ $\mathrm{PET} / \mathrm{CT}$. All serum were obtained after complete clotting by centrifugation, immediately frozen and stored at $-80 C^{\circ}$ until the time of analysis. Serum anti-p53 Abs levels were measured using Enzymelinked immuno sorbent assay (ELISA) kit (CUSABIO) according to the manufacturer's instructions. The kit was designed to measure circulating p53 antibodies in human serum samples. Intra-assay precision $\mathrm{CV}$ was $\%<8$ and inter-assay precision $\mathrm{CV}$ was $\%<10$. Limitation of the kit was only for research use and not for diagnostic procedure.

\section{Imaging Acquisitions/Analysis}

Positron Emission Tomography imaging was performed before the beginning of any treatment and images were acquired using a combined $\mathrm{PET} / \mathrm{CT}$ scanner (Discovery $600 \mathrm{PET} / \mathrm{CT}$ GE Medical Systems, USA). Each patient fasted for at least 6 hour before imaging. After ensuring that blood glucose was $<150 \mathrm{mg} / \mathrm{dl}$, approximately 370 $\mathrm{MBq}{ }^{18} \mathrm{~F}$ - FDG were administered i.v. 1 hour before image acquisition and patients were rested. Attenuation correction of PET images with CT data was performed. Firstly, CT scan was performed. Right after CT acquisition, a standard PET imaging protocol was taken from the cranium to the midthigh with an acquisition time of $3 \mathrm{~min} / \mathrm{bed}$ in 3dimensional mode. All PET studies were acquired in 3-D mode. CT images were acquired with 70 $\mathrm{mA}, 120 \mathrm{kV}$, axial slice thickness of $3.75 \mathrm{~mm}$. CT and PET images were matched and fused into transaxial, coronal and saggital images. The data were transferred via the Digital Imaging and Communications in Medicine (DICOM) protocol to a processing Workstation (AW Volume Share5 GE Medical Systems S.C.S, France). And then visual and semi-quantitative analysis was performed. Tumor size (three maximum diameters) was measured. SUV is a commonly applied semiquantitative parameter to express tumor FDG uptake. SUVmax, SUVmean and metabolic tumor volume (MTV) were calculated from attenuationcorrected ${ }^{18} \mathrm{~F}$-FDG PET images for tumor mass. The SUVmax was calculated by using the following formula: maximum pixel value with the ROI activity $(\mathrm{MBq} / \mathrm{kg}) /$ (injected dose $[\mathrm{MBq}] /$ body weight $[\mathrm{kg}]$ ). SUVmean was determined from the average voxel counts within the tumor region. Automatic volumes of interest (VOI) using an isocontour threshold method was placed over the primary tumor. TLG was then calculated as: "TLG=SUVmean X MTV".

\section{Statistical analysis}

The statistical tests were performed using SPSS (version 14.0; SPSS, Inc.). The frequencies test was applied to evaluate the statistical significance of the parameters. Correlations among serum anti-p53 Ab levels, tumor volume, tumor size, SUVmean, SUVmax, TLG and age were examined by the Spearman's rank correlation test. Relations between serum anti-p53 Ab levels and case groups, histopathological subtype of cancer patients and stage of cancer were evaluated by using Kruskal Wallis analysis due to parametric hypothesis could not be tested. Relation between serum anti-p53 levels and tobacco smoking status and sex of cases were evaluated with Mann-Whitney $U$ test. Survival rates were calculated according to the Kaplan-Meier method. A multivariate analysis (Cox regression analysis) was used to evaluate independent risk factors affecting survival. Significance levels were presented as $p$ values. It was assumed that the observed differences were statistically significant at the $\mathrm{p}<0.05$ levels.

\section{RESULTS}

A total of 65 LC patients (median age: 63 years, range $37-80 ; 58$ male/7 female), 47 patients with NAPN (median age: 57 years, range 22-80; 20 male/27 female), and a total of 34 healthy volunteers (median age: 63 years, range 44-89; 26 male/ 8 female) were included in this study. In our study $65.8 \%$ of men and $11.4 \%$ of women are cigarette-smoker $(p<0.001)$. General features of patients in our study are presented in (Table 1). 
Median serum anti-p53 Ab levels are $3.4 \mathrm{ng} / \mathrm{mL}$ (range:0.94-111.57 $\mathrm{ng} / \mathrm{mL}$ ) in LC patients, 3.77 $\mathrm{ng} / \mathrm{mL}$ (range:0.67-92.19 $\mathrm{ng} / \mathrm{mL}$ ) in NAPN patients, $3.07 \mathrm{ng} / \mathrm{mL}$ (range: $1.4-52 \mathrm{ng} / \mathrm{mL}$ ) in healthy volunteers. There is no statistically significant difference for serum anti-p53 Ab level in LC and NAPN patients. Moreover there is no statistically significant difference for serum antip53 Ab levels in patients and healthy volunteers ( $p=0.377$ ). In our lung cancer patients, there are 41 patients of squamous cell carcinoma, 13 patients of adenocarcinoma , 10 patients of small cell carcinoma and 1 patients of large cell carcinoma.
There are 7 stage I patients (10.8\%), 8 stage II patients $(12.3 \%), 19$ stage III patients $(29.2 \%)$ and 31 stage IV patients $(47.7 \%)$. In according to stage status the highest serum anti-p53 Ab levels were found in stage I patients. But this data was not statistically significant $(p=0.156)$. Median serum anti-p53 Ab level in 55 NSCLC patients was 3,4 $\mathrm{ng} / \mathrm{mL}$ (range: 0,94-111,57) and median serum anti-p53 Ab level in 10 SCLC patients was 2.01 $\mathrm{ng} / \mathrm{mL}$ (range:0,97-7,49) $(p=0.069)$. When taking into consideration all patients, median serum antip53 Ab levels of men was found higher than women $(p=0.003)$ (Table 2).

Table 1. General characteristics of the patient groups

\begin{tabular}{|l|c|c|c|c|}
\hline & $\begin{array}{c}\text { Control group } \\
34(23 \%)\end{array}$ & $\begin{array}{c}\text { NAPN } \\
47(32 \%)\end{array}$ & $\begin{array}{c}\text { Lung cancer } \\
65(45 \%)\end{array}$ & $p$ value \\
\hline Gender & & & & \\
Male & $26(76)$ & $20(43)$ & $58(89)$ & 0.001 \\
Female & $8(24)$ & $27(57)$ & $7(11)$ & \\
\hline Smoking status & & & & \\
Smoker & $25(74)$ & $37(79)$ & $7(11)$ & $<0.001$ \\
Nonsmoker & $9(26)$ & $10(21)$ & $58(89)$ & \\
\hline Age & $63(44-89)$ & $57(22-80)$ & $63(37-80)$ & 0.207 \\
\hline
\end{tabular}

Table 2. Patients and volunteers characteristics and comparison of serum anti-p53 Ab levels among these groups.

\begin{tabular}{|c|c|c|c|}
\hline & $\mathrm{N}(\%)$ & $\begin{array}{c}\text { p53 }(\mathrm{ng} / \mathrm{mL}) \\
\text { (median, range) }\end{array}$ & $p$ value \\
\hline $\begin{array}{l}\text { Gender } \\
\text { Female } \\
\text { Male }\end{array}$ & $\begin{array}{l}35(24) \\
111(76)\end{array}$ & $\begin{array}{l}2.77(0.67-89.20) \\
3.42(0.8-111.57)\end{array}$ & $0.003 *$ \\
\hline $\begin{array}{l}\text { Case groups } \\
\text { Lung cancer group } \\
\text { NAPN } \\
\text { Control group }\end{array}$ & $\begin{array}{l}65(45) \\
47(32) \\
34(23)\end{array}$ & $\begin{array}{c}3.4(0.94-111.57) \\
3.77(0.67-92.19) \\
3.07(1.4-52.0)\end{array}$ & 0.377 \\
\hline $\begin{array}{l}\text { Smoking status } \\
\text { Smoker } \\
\text { Nonsmoker }\end{array}$ & $\begin{array}{l}69(47) \\
77(53)\end{array}$ & $\begin{array}{c}3.2(0.67-92.19) \\
3.4(0.97-111.57)\end{array}$ & 0.316 \\
\hline $\begin{array}{l}\text { Histopathology } \\
\text { Squamous cell carcinoma } \\
\text { Adenocarcinoma } \\
\text { Small cell carcinoma } \\
\text { Large cell carcinoma }\end{array}$ & $\begin{array}{c}41(63) \\
13(20) \\
10(15) \\
1(2)\end{array}$ & $\begin{array}{c}3.16(1.09-111.57) \\
3.67(0.94-104.19) \\
2.01(0.97-7.49) \\
4.5^{*}\end{array}$ & 0.069 \\
\hline $\begin{array}{l}\text { Stage } \\
\text { Stage I } \\
\text { Stage II } \\
\text { Stage III } \\
\text { Stage IV }\end{array}$ & $\begin{array}{l}7(11) \\
8(12) \\
19(29) \\
31(48)\end{array}$ & $\begin{array}{c}4.74(0.94-111.57) \\
2.96(1.94-95.51) \\
3.94(1.12-81.18) \\
2.65(0.97-104.19)\end{array}$ & 0.156 \\
\hline
\end{tabular}

*Because it is a case of large cell carcinoma group, these patients were excluded from statistical analysis.

Median primary tumor size was found $55 \mathrm{~mm}$ (range:10-149) in lung cancer patients.Median tumor TLG value of primary tumor was found
410.221 (range:13-3068.7), median maximum standardized uptake value (SUVmax) of primary tumor was found 16.2 (range:7.9-58.1), in lung 
cancer patients. There is no statistically significant correlations between serum anti-p53 Ab level and tumor size, serum anti-p53 Ab level and TLG, serum anti-p53 Ab level and SUVmax $(\mathrm{p}=0.595$, $\mathrm{p}=0.218$ and $\mathrm{p}=0.884$, respectively) (Table 3 ).

Table 3. Correlation between $\mathrm{p} 53$ and age, p53 and tumor size, p53 and TLG, p53 and SUVmax

\begin{tabular}{|l|c|c|}
\hline & $r$ value & $p$ value \\
\hline Age & -0.185 & 0.140 \\
\hline Tumor size & -0.068 & 0.595 \\
\hline TLG & -0.156 & 0.218 \\
\hline SUVmax & -0.019 & 0.884 \\
\hline
\end{tabular}

Median serum anti-p53 Ab level was $3.4 \mathrm{ng} / \mathrm{mL}$. Mean follow up time was 13 months (range between 1-58 months). The median survival duration was 14 months and the 2-year survival rate was $31 \%$. Median survival rate was 13 months and 2-year survival rate was $36 \%$ in 33 patients whose serum anti-p53 Ab levels were $\leq 3.4 \mathrm{ng} / \mathrm{mL}$. Median survival rate was 15 months and 2-year survival rate was $28 \%$ in 32 patients whose serum anti-p53 Ab levels were $>3.4 \mathrm{ng} / \mathrm{mL}$ (Table 4). It has been found that there is no effect of serum antip53 Ab level whether $>3.4 \mathrm{ng} / \mathrm{mL}$ or $\leq 3.4 \mathrm{ng} / \mathrm{mL}$ on the patient survival rate $(\mathrm{p}=0.652)$ (Figure 1$)$. There was no statistically significant relationship between histopathologic subtype of tumor and whether serum anti-p53 Ab level $<3.4$ or $>3.4$ $(\mathrm{p}=0.550)$. There was no statistically significant correlation between age and serum anti-p53 $\mathrm{Ab}$ level $(\mathrm{p}=0.957, \mathrm{r}=0.004)$.

Table 4. Survival rates of lung cancer patients according to p53 values

\begin{tabular}{|l|c|c|c|}
\hline & $\begin{array}{c}\text { Median survival rates } \\
\text { (month) }\end{array}$ & $\begin{array}{c}2 \text { year survival rates } \\
(\%)\end{array}$ & $p$ value \\
\hline P53 value* & & 36 & 0.65 \\
$\leq 3.4$ & 13 & 28 & \\
$>3.4$ & 15 & 0
\end{tabular}

*Median p53 value was 3.4 in lung cancer patients in our study and therefore survival analysis was done according to this value.

Survival Functions

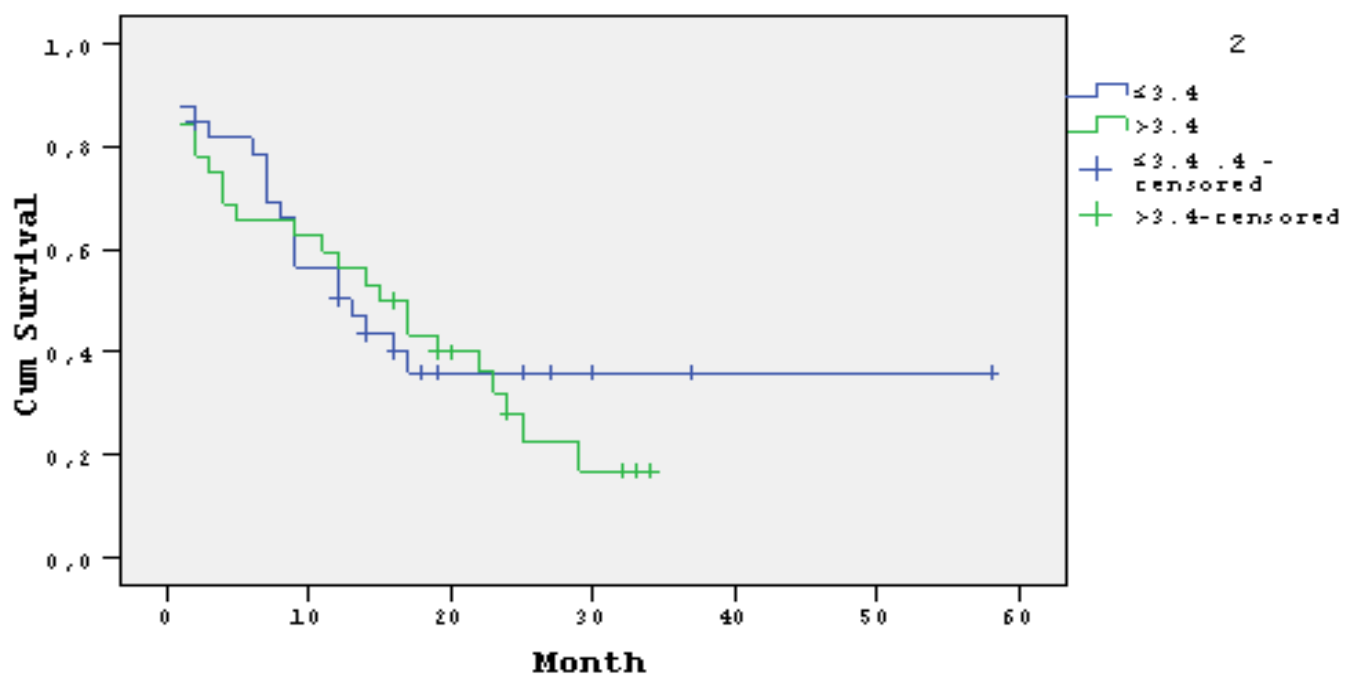

Figure 1. Survival curves for lung cancer patients according to the serum anti p-53 Ab levels. 
In 3 of healthy volunteers serum anti-p53 Ab levels were found high in according to median serum antip53 value of healthy volunteers (median serum anti-p53 Ab level:3.07 ng/mL; these healthy volunteers serum-p53 Ab levels: $25.72 \mathrm{ng} / \mathrm{mL}, 52$ $\mathrm{ng} / \mathrm{mL}$ and $43.35 \mathrm{ng} / \mathrm{mL}$ ) . One of the volunteers had almost 45 years of smoking history. Thorax CT was performed to that volunteer. There could not be found any mass or nodule. However an emphysema was detected. But thorax CT was not performed another two volunteers.

Two of the patients (in LC group) included in the study had cancer history before. The disease free period was over 10 years. Both of the patients were in complete remission and follow up. One of them was colon cancer and the other was renal cell carcinoma. While serum anti-p53 Ab level was $52.49 \mathrm{ng} / \mathrm{mL}$ in patient with colon cancer, it was $3.45 \mathrm{ng} / \mathrm{mL}$ in patient with renal cell carcinoma.

There were statistically significant difference of serum anti-p53 Ab levels between male and female patients in LC and NAPN groups $(\mathrm{p}=0.030$ and $\mathrm{p}=0.021$, respectively) but in healthy volunteers group there was not statistically significant difference of serum anti-p53 Ab levels between male and female patients $(\mathrm{p}=0.436)$ (Table 5). When evaluated seperately there were not statistically significant difference of serum antip53 Ab levels between smoker and nonsmoker patients in LC, NAPN and healthy volunteers group ( $\mathrm{p}=0.568 ; \mathrm{p}=0.297 ; \mathrm{p}=0.565$, respectively) (Table 6).

Table 5. Comparision of serum anti-p53 Ab levels between male and female patients in LC, NAPN and healthy volunteers groups.

\begin{tabular}{|c|l|l|c|}
\hline & $\begin{array}{l}\text { Male } \mathrm{n}(\%)(\text { serum anti-p53 } \\
\text { Ab level-ng/mL) }\end{array}$ & $\begin{array}{l}\text { Female } \mathrm{n}(\%)(\mathrm{serum} \text { anti- } \\
\mathrm{p} 53 \mathrm{Ab} \text { level-ng/mL) }\end{array}$ & $\begin{array}{c}p \\
\text { value }\end{array}$ \\
\hline Patients Groups & & & \\
\hline LC & $58(89.2)(11.29 \pm 24)$ & $7(10.8)(2.28 \pm 1.1)$ & $* 0.03$ \\
\hline NAPN & $27(57.4)(14.79 \pm 26)$ & $20(42.6)(7.56 \pm 19)$ & $* 0.021$ \\
\hline Healthy Volunteers & $26(76.5)(7.22 \pm 12)$ & $8(23.5)(2.8 \pm 0.8)$ & 0.436 \\
\hline
\end{tabular}

Table 6. Comparision of serum anti-p53 Ab levels between smoker and nonsmoker patients in LC, NAPN and healthy volunteers groups.

\begin{tabular}{|c|l|l|l|}
\hline Smoking status & $\begin{array}{l}\text { LC n (\%) (serum anti- } \\
\text { p53 Ab level-ng/mL) }\end{array}$ & $\begin{array}{l}\text { NAPN n (\%) (serum } \\
\text { anti-p53 Ab level- } \\
\text { ng/mL) }\end{array}$ & $\begin{array}{l}\text { Healthy Volunteers n (\%) } \\
\text { (serum anti-p53 Ab level- } \\
\text { ng/mL) }\end{array}$ \\
\hline Smoker & $58(89.2)(1.19 \pm 25)$ & $10(21.3)(9.8 \pm 17)$ & $9(26.5)(10.77 \pm 17)$ \\
\hline Nonsmoker & $7(10.8)(3.09 \pm 1)$ & $37(78.7)(12.3 \pm 25)$ & $25(73.5)(4.53 \pm 8)$ \\
\hline$p$ value & 0.568 & 0.297 & 0.565 \\
\hline
\end{tabular}

\section{DISCUSSION}

Some tumor markers are used for diagnosis and patient follow up in certain types of cancers. But there is no current tumor marker for lung cancer and only imaging methods are used for this purpose. But using of this imaging modalities are limited because of radiation exposure. Suspicious lesions which detected in thorax CT are evaluated with ${ }^{18} \mathrm{~F}$-FDG PET/CT. This method give chance of anatomical and metabolic evaluation of lesion. But some studies about tumor-associated antibodies have been done with the aim of increasing 
diagnostic accuracy and early diagnosis ${ }^{13}$. Recent studies showed that tumor antigens causes spesific immun response in lung cancer patients. Anti- P53 $\mathrm{Ab}$ is most studied tumor antigen in this group. TP53 tumor suppresor gene mutations can induce an immune response and anti-p53 Ab can occur early in the carcinogenic process for some tumors ${ }^{14}$. Although detection frequency of serum anti-p53 Ab is low, specificity of p53 autoantibodies for cancer was found high in cohort studies. Lei at al ${ }^{15}$ reported that anti-p53 antibody can be an assistant marker in diagnosing lung cancer, but the low sensitivity limits its use as a screening tool for lung cancer in 4414 subjected meta-analysis. Wu et al ${ }^{9}$ do a scientific research about association of serum p53 protein and antibodies with malignant tumors ;case-control study was conduct in 569 patients with various types of malignant tumors and 879 healthy controls. They found that the rate of anti-p53 antibodies in patients with various malignant tumors was $14.59 \%$ compared with $1.02 \%$ in healthy controls. They suggest that serum p53 protein and antibody are associated with increased cancer risk and can be used as early serological markers in the diagnosis of malignancies tumors. Mattioni et al ${ }^{16}$ was found that the presence of serum p53Abs was found to be associated with smoking level and lung function impairment, both risk factors of cancer development in 675 subjected multicenter study. However they did not observe the occurrence of lung cancer or other cancers in the follow-up of positive subjects in a median follow-up of 24 months. In our study; we found that there is no significant difference of serum anti-p53 $\mathrm{Ab}$ levels among healthy volunteers, LC patients, NAPN patients. Moreover the prognostic role of anti-p53 antibodies in lung cancer remains opposite and as some studies show an association with poor prognosis, others show no relation between survival and anti-p53 Abs ${ }^{17}$. Ciancino et al. ${ }^{18}$ found that via fiberoptic bronchial biopsies of NSCLC patients; p53 negative patients had a in significantly higher survival rates than $\mathrm{p} 53$ positive patients. Lai et al ${ }^{19}$ reported that, the anti-p53 Ab positive lung cancer patients had a worse prognosis than the anti-p53 Ab negative patients. In this study they found that median survival time 20 weeks in anti-p53 Ab positive patients and 41 weeks in antip53 Ab negative patients. When the median serum anti-p53 Ab level was taken as $3.4 \mathrm{ng} / \mathrm{ml}$; It has been found that there is no effect of serum anti-p53 Ab level whether $>3.4 \mathrm{ng} / \mathrm{mL}$ or $\leq 3.4 \mathrm{ng} / \mathrm{mL}$ on the patient survival rate $(\mathrm{p}=0.652)$. It is known that incidence of p53 gene mutations is higher in aggressive SCLC patients than NSCLC patients ${ }^{20}$. Zalcman et $\mathrm{al}^{21}$ found that survival rates of serum anti $\mathrm{p} 53 \mathrm{Ab}$ positive patients is shorter than serum anti p53 Ab negative patients in their study with limited-stage small cell lung cancer patients. In literature higher incidence of p53 gene mutations are seen in SCLC patients than NSCLC patients. But in our study it was found that anti-p53 Ab levels were higher in NSCLC patients than SCLC patients (although there was not statistically significant) (Table 2). Yu et al [22] reported that serum -p53 Abs remarkably decreased after neoadjuvant chemotheraphy treatment and preneoadjuvant chemotheraphy low serum-p53 Abs correlated with high objective chemoresponse rate in 47 stage III NSCLC patients.

FDG-PET is routinely used non invasive imaging tecnique in worldvide by means of its capability for demonstrating high glucose activity in malignant tumors. Duan et al ${ }^{23}$ evaluated that are there any relationship between the expressions of chemotherapy resistance related tumor markers and SUVmax value of tumor in ${ }^{18} \mathrm{~F}$-FDG PET/CT. And they have been showed that there is positive correlation between the expressions of p53 and SUVmax on FDG-PET in NSCLCs. So they reported that FDG-PET might be a simple and good non-invasive method for predicting p53-related chemotherapy resistance in NSCLCs. Distinctly, another study suggested that there was no association between p53 expression and FDG uptake in NSCLC patients ${ }^{24}$. In our study, there is no statistically significant correlations between serum anti-p53 Ab level and tumor size, serum anti-p53 Ab level and TLG. Interestingly in our study we found that median serum anti-p53 Ab levels in man patients was found higher than woman patients (Table2). It is thought that this condition may be related with cigarette smoking. Because in our study; $65.8 \%$ of man subjects and $11.4 \%$ of woman subjects were cigarette smoker. Cigarette smoking ratio was highest in lung cancer patients (Table 1). However there was no statistically significant relationship between cigarette smoking and serum anti-p53 Ab levels in our study. Whereas we had been found statistically significant relationship between cigarette smoking and serum anti-p53 Ab levels in our preliminary study ${ }^{25}$. But we think that this condition may be related with patient number.

Hypoxia induces $\mathrm{p} 53$ protein accumulation and $\mathrm{p} 53$ dependent apoptosis in oncogenically transformed cells. Hypoxic tumors have more aggressive nature with compared to well-oxygenated ones and p53 mutations are seen more frequent in advanced stages of tumor development ${ }^{26}$. In our study there was no statistically significant difference for serum anti-p53 Ab level in LC and 
NAPN patients. This situation may be related with hypoxic state of subjects It is claimed that overexpression of some angiogenic factors such as hypoxia inducible factor-1A may be a prediposing factors of lung fibrosis like sarcoidosis and overexpression of these factors may be responsible for FDG uptake in lung cancer ${ }^{27}$. For explaining this situation, new studies are required.

\section{CONCLUSION}

In our study there was no statistically significant difference of serum anti-p53 Ab levels between lung cancer patients and NAPN patients. Therefore we think that this antibody is not tumor spesific and serum anti-p53 $\mathrm{Ab}$ level measurement is not appropriate for lung cancer screening. Even though serum anti-p53 $\mathrm{Ab}$ is very important in carcinogenesis, we think that serum anti-p53 Ab level by itself is not important in lung cancer diagnosis and survival rate. There are multiple factors in carcinogenesis and this may be the reason of this situation. There is no known cut off serum value of anti-p53 $\mathrm{Ab}$ for lung cancer patients.

Funding: This work was supported by grants from Cumhuriyet University Scientific Research Project Unit (T-597).

Conflict of Interest: Zekiye Hasbek declares that she has no conflict of interest. Birsen Yücel declares that she has no conflict of interest. Omer Tamer Dogan declares that he has no conflict of interest. Serdar Berk declares that he has no conflict of interest. Ismail Sarı declares that he has no conflict of interest. Yavuz Silig declares that he has no conflict of interest. Mehmet Metin Seker declares that he has no conflict of interest. Seyit Ahmet Ertürk declares that he has no conflict of interest.

Ethical approval: All procedures performed in studies involving human participants were in accordance with the ethical standards of the institutional research committee and with the 1964 Helsinki declaration and its later amendments or comparable ethical standards.

\section{REFERENCES}

1- Jemal A, Siegel R, Xu J, Ward E. Cancer statistics, 2010. CA Cancer J Clin. 2010; 60:277-300. Erratum in, CA Cancer J Clin. 2011; 61: 133-4.

2- Huang W, Zhou T, Ma L, Sun H, Gong H, Wang J, Yu J, Li B. Standard uptake value and metabolic tumor volume of ${ }^{18} \mathrm{~F}-\mathrm{FDG}$ PET/CT predict short-term outcome early in the course of chemoradiotherapy in advanced non-small cell lung cancer. Eur $\mathrm{J}$ Nucl Med Mol Imaging. 2011; 38: 1628-35.

3- National Lung Screening Trial Research Team, Aberle DR, Adams AM, Berg CD, Black WC, Clapp JD, Fagerstrom RM, Gareen IF, Gatsonis C, Marcus PM, Sicks JD. Reduced lung-cancer mortality with low-dose computed tomographic screening. N Engl J Med 2011,4; 365: 395-409.

4- Schaarschmidt BM, Grueneisen J, Metzenmacher M, Gomez B, Gauler T, Roesel C, Heusch P, Ruhlmann V, Umutlu L, Antoch G, Buchbender C. Thoracic staging with ${ }^{18} \mathrm{~F}$ FDG PET/MR in non-small cell lung cancer does it change therapeutic decisions in comparison to ${ }^{18} \mathrm{~F}$-FDG PET/CT? Eur Radiol 2016. doi: 10.1007/s00330-016-4397-0.

5- Kitajima K, Doi H, Kanda T, Yamane T, Tsujikawa T, Kaida H, Tamaki Y, Kuribayashi $\mathrm{K}$. Present and future roles of FDG-PET/CT imaging in the management of lung cancer. Jpn J Radiol 2016; 34: 387-99.

6- Park S, Lee E, Rhee S, Cho J, Choi S, Lee S, Eo JS, Pahk K, Choe JG, Kim S. Correlation between Semi-Quantitative (18) F-FDG PET/CT Parameters and Ki-67 Expression in Small Cell Lung Cancer. Nucl Med Mol Imaging 2016; 50: 24-30.

7- Woodard KM, Chapman CJ. Lung cancer can autoantibodies provide an aid to diagnosis? Expert Opin Med Diagn 2008; 2: 911-23.

8- Gao RJ, Bao HZ, Yang Q, Cong Q, Song JN, Wang L. The presence of serum anti-p53 antibodies from patients with invasive ductal carcinoma of breast: correlation to other clinical and biological parameters. Breast Cancer Res Treat 2005; 93: 111-5.

9- Wu M, Mao C, Chen Q, Cu XW, Zhang WS. Serum $\mathrm{p} 53$ protein and anti-p53 antibodies are associated with increased cancer risk: a casecontrol study of 569 patients and 879 healthy controls. Mol Biol Rep 2010; 37: 339-43.

10- Fernández Madrid F. Autoantibodies in breast cancer sera: candidate biomarkers and reporters of tumorigenesis. Cancer Lett 2005,18; 230: 187-98.

11- Garziera M, Montico M, Bidoli E, Scalone S, Sorio R, Giorda G, Lucia E, Toffoli G. Prognostic Role of Serum Antibody Immunity to p53 Oncogenic Protein in Ovarian Cancer: A Systematic Review and a Meta-Analysis. 
PLoS One 2015, 9; 10: e0140351.

12- Zhang H, Xia J, Wang K, Zhang J. Serum autoantibodies in the early detection of esophageal cancer: a systematic review. Tumour Biol 2015; 36: 95-109.

13- Healey GF, Lam S, Boyle P, Hamilton-Fairley G, Peek LJ, Robertson JF. Signal stratification of autoantibody levels in serum samples and its application to the early detection of lung cancer. J Thorac Dis 2013; 5: 618-25.

14- Li Y, Karjalainen A, Koskinen H, Hemminki K, Vainio H, Shnaidman M, Ying Z, Pukkala E, Brandt-Rauf PW. p53 autoantibodies predict subsequent development of cancer. Int J Cancer 2005, 10;114: 157-60.

15- Lei QQ, Liu JW, Zheng H. Potential role of anti-p53 antibody in diagnosis of lung cancer: evidence from a bivariate meta-analysis. Eur Rev Med Pharmacol Sci 2013; 17: 3012-8

16- Mattioni M, Chinzari P, Soddu S, Strigari L, Cilenti V, Mastropasqua E. Serum p53 antibody detection in patients with impaired lung function. BMC Cancer 2013; 6: 13:62.

17- Kumar S, Mohan A, Guleria R. Prognostic implications of circulating anti-p53 antibodies in lung cancer--a review. Eur J Cancer Care (Engl) 2009; 18: 248-54.

18- Ciancio N, Galasso MG, Campisi R, Bivona L, Migliore M, Di Maria GU. Prognostic value of p53 and Ki67 expression in fiberoptic bronchial biopsies of patients with non small cell lung cancer. Multidiscip Respir Med 2012; 14: 7: 29.

19- Lai CL, Tsai CM, Tsai TT, Kuo BI, Chang KT, Fu HT, Perng RP, Chen JY. Presence of serum anti-p53 antibodies is associated with pleural effusion and poor prognosis in lung cancer patients. Clin Cancer Res 1998; 4: 3025-30.

20- Winter SF, Minna JD, Johnson BE, Takahashi T, Gazdar AF, Carbone DP. Development of antibodies against p53 in lung cancer patients appears to be dependent on the type of p53 mutation. Cancer Res 1992, 1; 52: 4168-74.

21- Zalcman G, Trédaniel J, Schlichtholz B, Urban T, Milleron B, Lubin R, Meignin V, Couderc LJ, Hirsch A, Soussi T. Prognostic significance of serum p53 antibodies in patients with limited-stage small cell lung cancer. Int J Cancer 2000, 20; 89: 81-6.

22- Yu DH, Li JH, Wang YC, Xu JG, Pan PT, Wang L. Serum anti-p53 antibody detection in carcinomas and the predictive values of serum p53 antibodies, carcino-embryonic antigen and carbohydrate antigen $12-5$ in the neoadjuvant chemotherapy treatment for III stage non-small cell lung cancer patients. Clin Chim Acta 2011,12; 412: 930-5.

23- Duan XY, Wang W, Wang JS, Shang J, Gao JG, Guo YM. Fluorodeoxyglucose positron emission tomography and chemotherapyrelated tumor marker expression in non-small cell lung cancer. BMC Cancer 2013,15; 13: 546.

24- Nakamura $H$, Hirata $T$, Kitamura $H$, Nishikawa J. Correlation of the standardized uptake value in FDG-PET with the expression level of cell-cycle-related molecular biomarkers in resected non-small cell lung cancers. Ann Thorac Cardiovasc Surg 2009; 15: 304-10.

25- Hasbek Z, Doğan OT, Sarı I, Yücel B, Şeker MM, Turgut B, Berk S, Siliğ Y. The Diagnostic Value of the Correlation between Serum Anti-p53 Antibody and Positron Emission Tomography Parameters in Lung Cancer. Mol Imaging Radionucl Ther 2016, 5; 25: 107-113.

26- Koumenis C, Alarcon R, Hammond E, Sutphin P, Hoffman W, Murphy M, Derr J, Taya Y, Lowe SW, Kastan M, Giaccia A. Regulation of $\mathrm{p} 53$ by hypoxia: dissociation of transcriptional repression and apoptosis from p53-dependent transactivation. Mol Cell Biol 2001; 21: 1297-310.

27- van Baardwijk A, Dooms C, van Suylen RJ, Verbeken E, Hochstenbag M, Dehing-Oberije C, Rupa D, Pastorekova S, Stroobants S, Buell U, Lambin P, Vansteenkiste J, De Ruysscher D. The maximum uptake of (18)Fdeoxyglucose on positron emission tomography scan correlates with survival, hypoxia inducible factor-1alpha and GLUT-1 in non-small cell lung cancer. Eur J Cancer 2007; 43: 1392-8. 